\title{
Retinoblastoma cT2 TNM Finding v8
}

National Cancer Institute

\section{Source}

National Cancer Institute. Retinoblastoma CT2 TNM Finding v8. NCI Thesaurus. Code C140688.

Intraocular tumor(s) with retinal detachment, vitreous seeding, or subretinal seeding. (from AJCC 8th Ed.) 